\title{
RANCANG BANGUN LOW POWER ELEKTRIC SURGERY (PISAU BEDAH LISTRIK) PADA FREKUENSI $10 \mathrm{KHz}$
}

\author{
Teguh Firmansyah*, Rocky Alfanz, Windra Bagus Suwandidan \\ Jurusan Teknik Elektro, Fakultas Teknik, Universitas Sultan Ageng Tirtayasa \\ *Corresponding author, e-mail : teguhfirmansyah@untirta.ac.id
}

\begin{abstract}
Abstrak - Pada penelitian ini diusulkan rancang bangun low power elektro surgery (LPES), pisau bedah listrik, pada frequency $10 \mathrm{KHz}$ yang digunakan dalam pengujian daging. Alat ini terdiri dari rangkaian power supply, regulator tegangan, dan pencacah frequency. Tujuan penelitian ini diharapkan meminimalisir terjadinya spark over dan terjadinya luka bakar. Hasil pengukuran menunjukan bahwa alat ini bekerja dengan daya sebesar 26 Watt dan frekuensi sebesar 11,16 KHz. Electric surgery ini diuji coba terhadap daging kerbau, daging kambing, dan daging sapi. Pada daging sapi dengan menggunakan tegangan 28,7 Volt membutuhkan waktu 51 detik, dengan menggunakan tegangan 28,1 Volt membutuhkan waktu 53 detik, dengan menggunakan tegangan 27,8 Volt membutuhkan waktu 57 detik. Pada daging kambing dengan menggunakan tegangan 28,7 Volt membutuhkan waktu 30 detik, dengan menggunakan tegangan 28,1 Volt membutuhkan waktu 41 detik, dengan menggunakan tegangan 27,8 Volt membutuhkan waktu 49 detik. Pada daging kerbau dengan menggunakan tegangan 28,7 Volt membutuhkan waktu 52 detik, dengan menggunakan tegangan 28,1 Volt membutuhkan waktu 56 detik, dengan menggunakan tegangan 27,8 Volt membutuhkan waktu 59 detik. Jika dibandingkan dengan hasil penelitian lainnnya, penelitian ini memiliki daya rendah dan frekuensi rendah, sehingga dapat meminimalisir terjadinya spark over dengan kecepatan proses pemotongan yang baik.
\end{abstract}

Kata Kunci : Pisau bedah listrik, low power, spark over, kecepatan pemotoangan.

\begin{abstract}
In this study, It is proposed a design of electric surgery on $10 \mathrm{KHz}$. This device consists of a power supply circuit, a voltage regulator, and a frequency counter. The purpose of this study is expected to minimize the occurrence of spark overs and the occurrence of burns. The measurement results show that LPES is working with a power of 26 watts and a frequency of $11.16 \mathrm{KHz}$. Electric surgery was tested against buffalo meat, mutton and beef. In beef by applying a voltage of 28.7 volts takes 51 seconds, using a voltage of 28.1 volts takes 53 seconds, using a voltage of 27.8 volts takes 57 seconds. In goat meat by using a voltage of 28.7 volts takes 30 seconds, using a voltage of 28.1 volts takes 41 seconds, using a voltage of 27.8 volts takes 49 seconds. In buffalo meat by using a voltage of 28.7 volts takes 52 seconds, using a voltage of 28.1 volts takes 56 seconds, using a voltage of 27.8 volts takes 59 seconds. Compare to another electric surgery, this study had low power and low frequency, so as to minimize the occurrence of spark over with good speed cutting process.
\end{abstract}

Keywords : Electric surgery, low power, spark over, speed cutting.

Copyright $\odot 2016$ JNTE. All rights reserved

\section{PENDAHULUAN}

Perkembangan ilmu pengetahuan dan teknologi khususnya teknologi kedokteran maka dikembangkan suatu alat bedah dengan memanfaatkan teknologi diantaranya Pisau bedah sudah banyak dibuat salah satunya ESU dengan merk radiotom yang dalam penggunaannya lebih banyak keuntungannya dibandingkan dengan alat bedah konvensional [1]. Pisau bedah listrik adalah suatu alat bantu yang digunakan untuk pembedahan ringan dalam operasi, karena kemampuannya untuk membedah dan sekaligus membakar jaringan, sehingga akan mengurangi pendarahan saat pembedahan. Pisau bedah listrik menggunakan prinsip loncatan muatan listrik dalam pembedahan jaringan, atau kontak elektroda dengan jaringan tidak diperlukan. Dengan efek loncatan elektron yang membakar jaringan maka hasil pembedahan akan lebih steril [1].

Electrosurgery adalah suatu alat bedah medis yang memanfaatkan frekwensi tinggi dari arus listrik yang digunakan untuk memotong, mengental, dan mengeringkan jaringan. Electrosurgical adalah alat medis yang selalu 
digunakan selama proses operasi [2]. Dengan menggunakan alat ini diharapkan selama proses operasi, pasien tidak mengalami kehilangan banyak darah karena alat ini selaian dapat digunakan untuk melakukan pembedahan juga dapat digunakan untuk menutup jaringan setelah mengalami pembedahan. Kemajuan teknologi membuat electrosurgical ini menjadi wajib digunakan dalam selama proses pembedahan [2].

Beberapa penelitian electric surgery diantaranya Ansell Cares [3], Australia yang memuat tentang information and educational program for the hospital and medical community [3]. Tinjauan bedah elektro dan sarung tangan lateks dimana membahas tentang. Masalah lain yang berkaitan dengan penggunaan bedah elektro yang berkaitan dengan shock atau luka bakar listrik pada ahli bedah yang melakukan operasi. Namun terjadi luka bakar saat melakukan operasi, karena itu sebaiknya jangan 'diandalkan memberikan isolasi yang tidak akan pernah gagal'. Sementara pada penelitian Daniel Palanker [4], Stanford University Amerika. Memuat informasi mechanisms of interaction in electrosurgery.Penelitian ini memuat tentang mekanisme penggunaan dari electrosurgery menggunaka frequency $4 \mathrm{MHz}$ dan Tegangan $100 \mathrm{~V}$ sampai $700 \mathrm{~V}$ dengan menggunakan arus sebesar 0.3 Ampere sampai 0.8 Ampere. Namun dengan penelitian ini alat harus menggunakan daya besar dalam penggunaannya. Penelitian lainnya yaitu Joko Sunardi [5], STTN-BATAN Yogyakarta. Memuat informasi Rancang Bangun Pisau Bedah Listrik Dengan Frequency 450 Khz. Penelitian ini membuat pisau bedah listrik dengan frequency $450 \mathrm{KHz}$ dengan menggunakan daya 47.97 Watt. Namun pada rancang bangun pisau bedah listrik ini harus menggunakan daya yang cukup besar dalam penggunaannya .

Sebagai state of the art, pada penelitian ini diusulkan perancangan rangkaian electric surgery berbasis menggunakan frequency yang rendah dan menggunakan daya rendah pula dalam penggunaanya (LPES). Penelitian ini memiliki beberapa kelebihan diantaranya peningkatan safety dari permasalahan, Tabel 1 . Memperlihatkan posisi penelitian:

1. Arus bocor,

2. Grounding yang tidak bagus.

3. Tahanan isolasi yang kurang baik.

4. Spark over yang berlebihan

5. Peningkatan kinerja.
6. Low power consumtion.

Tabel 1. Posisi penelitian

\begin{tabular}{|c|c|c|c|}
\hline Penelitian & Daya & Freq & Review \\
\hline $\begin{array}{c}\text { Joko } \\
\text { Sunardi } \\
\text { M.Fajri } \\
\text { Toto } \\
\text { Trikasjono }\end{array}$ & $\begin{array}{l}47,97 \\
\text { Watt }\end{array}$ & $\begin{array}{l}450 \\
\mathrm{KHz}\end{array}$ & $\begin{array}{ll}\text { 1. } & \text { Daya Tinggi } \\
& \text { Memungkinkan } \\
& \text { Terjadinya Spark } \\
& \text { Over Terhadap } \\
& \text { Objek Dalam } \\
& \text { Pengoprasian } \\
\text { 2. } & \text { Membutuhkan } \\
& \text { Frequency Tinggi } \\
& \text { Dalam } \\
& \text { Pengoprasiannya }\end{array}$ \\
\hline $\begin{array}{l}\text { Imam } \\
\text { Abdi } \\
\text { Bangkit } \\
\text { Anggun } \\
\text { Dyah } \\
\text { Syawitri }\end{array}$ & $\begin{array}{c}80 \\
\text { Watt }\end{array}$ & $\begin{array}{c}2 \\
\mathrm{MHz}\end{array}$ & $\begin{array}{ll}1 . & \text { Daya Tinggi } \\
& \text { Memungkinkan } \\
& \text { Terjadinya Spark } \\
& \text { Over Terhadap } \\
& \text { Objek Dalam } \\
& \text { Pengoprasian } \\
\text { 2. } & \text { Membutuhkan } \\
& \text { Frequency Tinggi } \\
& \text { Dalam } \\
& \text { Pengoprasiannya } \\
\end{array}$ \\
\hline $\begin{array}{c}\text { Penelitian } \\
\text { ini }\end{array}$ & $\begin{array}{c}26 \\
\text { Watt }\end{array}$ & $\begin{array}{l}11,16 \\
\mathrm{KHz}\end{array}$ & $\begin{array}{ll}1 . & \text { Daya Rendah } \\
\text { Sehingga } \\
\text { Memungkinkan } \\
\text { Untuk } \\
\text { Meminimalisir } \\
\text { Terjadinya Spark } \\
\text { Over Dalam } \\
\text { 2engoprasiannya } \\
\text { 2. } \\
\text { Hanya } \\
\text { membutuhkan } \\
\text { Frequency Rendah } \\
\text { Dalam } \\
\text { Penggunaannya }\end{array}$ \\
\hline
\end{tabular}

\section{TINJAUAN PUSTAKA}

Pada penelitian ini digunakan beberapa subsistem diantaranya rangkaian power supply, regulator tegangan, dan pencacah frequency.

Power supply adalah suatu alat listrik yang dapat menyediakan energi listrik untuk perangkat listrik ataupun elektronika lainnya. Pada dasarnya Power Supply atau Catu daya ini memerlukan sumber energi listrik yang kemudian mengubahnya menjadi energi listrik yang dibutuhkan oleh perangkat elektronika lainnya. Oleh karena itu, Power Supply kadangkadang disebut juga dengan istilah Electric Power Converter [4]. Gambar 1 merupakan gambar schematic power supply.

Adanya perubahan pada masukan AC dan variasi beban merupakan penyebab utama terjadinya ketidakstabilan pada power supply. Pada sebagian peralatan elektronika, terjadinya perubahan catu daya akan berakibat cukup serius. Untuk mendapatkan pencatu daya yang stabil diperlukan regulator tegangan. Regulator 
tegangan untuk suatu power supply paling sederhana adalah menggunakan dioda zener [6][7].

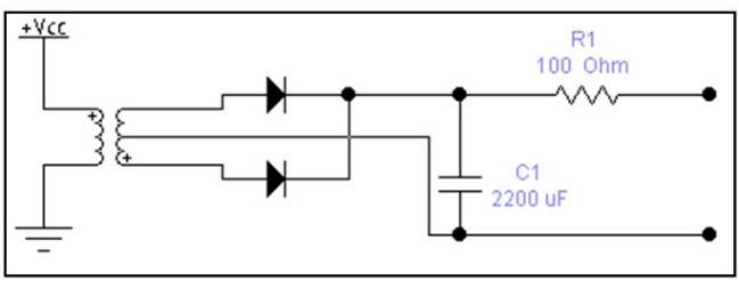

Gambar 1. Schematic Power Supply

Rangkaian dasar penggunaan dioda zener sebagai regulator tegangan dapat dilihat pada Gambar 2.

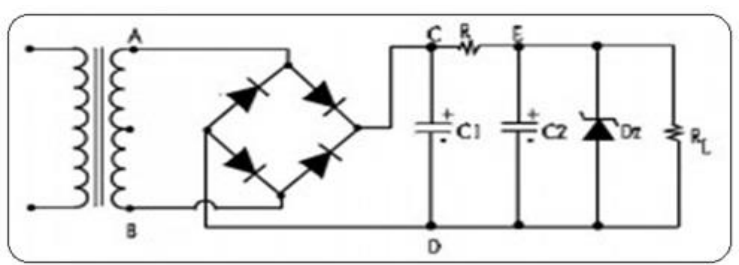

Gambar 2. Rangkaian Regulator Tegangan

Rangkaian pencatu daya (power supply) dengan regulator diode zener pada gambar rangkaian diatas, merupakan contoh sederhana cara pemasangan regulator tegangan dengan dioda zener. Diode zener dipasang paralel atau shunt dengan L dan $\mathrm{R}$. Regulator ini hanya memerlukan sebuah diode zener terhubung seri dengan resistor RS . Perhatikan bahwa diode zener dipasang dalam posisi reverse bias. Dengan cara pemasangan ini, diode zener hanya akan berkonduksi saat tegangan reverse bias mencapai tegangan breakdown dioda zener. Penyearah berupa rangkaian diode tipe jembatan (bridge) dengan proses penyaringan atau filter berupa filter-RC. Resistor seri pada rangkaian ini berfungsi ganda. Pertama, resistor ini menghubungkan $\mathrm{C} 1$ dan $\mathrm{C} 2$ sebagai rangkaian filter. Kedua, resistor ini berfungsi sebagai resistor seri untuk regulator tegangan (dioda zener). Diode zener yang dipasang dapat dengan sembarang dioda zener dengan tegangan breakdown misal dioda zener 9 volt. Tegangan output transformer harus lebih tinggi dari tegangan breakdown dioda zener, misalnya untuk penggunaan dioda zener 9 volt maka gunakan output transformer 12 volt [8-9].
Rangkaian inverter adalah rangkaian elektronika yang berfungsi untuk mengubah tegangan listrik DC (arus searah) menjadi tegangan AC (bolak-balik). Umumnya rangkaian ini digunakan untuk mendapatkan tegangan ac yang sesuai dengan tegangan PLN (220 volt) dengan memanfaatkan baterai atau aki yang mempunyai tengangan arus searah. Rangkaian ini bisa diaplikasikan pada berbagai fungsi mulai dari kebutuhan rumah tangga sampai industri [10-11].

\section{METODOLOGI PENELITIAN}

Metode pada penelitian ini terlihat pada diagram alir pada Gambar 3.

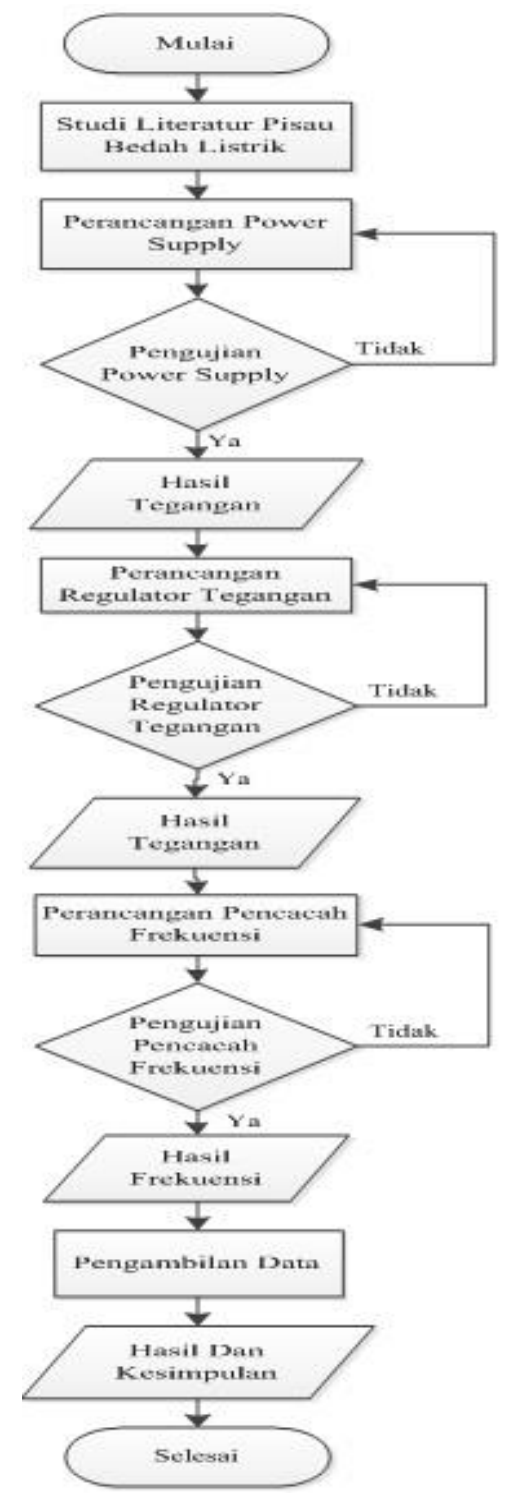

Gambar 3. Diagram Alir Penelitian 
Seperti terlihat pada Gambar 4. Pada perancangan Alat Pisau Bedah pada penelitian ini terbagi menjadi tiga bagian utama, antara lain adalah :

1. Power supply dimana digunakan sebagai penyuplai tegangan dari tegangan $\mathrm{AC}$ dirubah menjadi tegangan DC terhadap alat yang dirancang.

2. Regulator tegangan dimana digunakan sebagai penstabil tegangan yang dihasilkan oleh power supply.

3. Pencacah frequency dimana digunakan sebagai pencacah gelombang DC. Perancangan alat ini berfungsi sebagai alat pisau bedah yang menggunakan gelombang DC yang dicacah oleh transitor 2N3055 sebagai pencacahnya yang akan menghasilkan sinyal frequency.

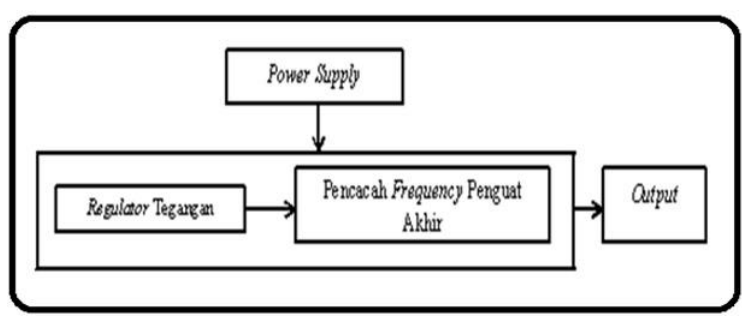

Gambar 4. Blok Diagram Pisau Bedah

Cara kerjanya yaitu pada saat control voltage mendapatkan suplai dari tegangan PLN 220 Volt, main switch di-ON, maka rangkaian power supply akan memberikan suplai tegangan ke seluruh blok rangkaian [11]-[12]. Maka rangkaian regulator tegangan \& penguat aruspun bekerja dengan hasil tegangan berubah gelombang sinyal DC dengan arus yang besar. Kemudian diteruskan ke rangkaian inverter penguat akhir yang berfungsi sebagai pencacah gelombang sinyal DC yang dicacah dengan transistor, transistor yang diguakan adalah transistor 2N3055 yang dimana transistor ini merupakan jenis transistor daya tinggi serta menggunakan trafo step up sebagai penguat akhir yang dapat digunakan untuk proses cutting. Setelah itu output dari rangkaian penguat akhir ini melewati elektroda aktif yang akan digunakan untuk menemui objek.

\subsection{Power Supply DC}

Power supply adalah suatu alat listrik yang dapat menyediakan energi listrik untuk perangkat listrik ataupun elektronika lainnya
[13]. Pada dasarnya Power Supply atau Catu daya ini memerlukan sumber energi listrik yang kemudian mengubahnya menjadi energi listrik yang dibutuhkan oleh perangkat elektronika lainnya [14]. Oleh karena itu, Power Supply kadang-kadang disebut juga dengan istilah Electric Power Converter. Dalam perancangan power supply ada beberapa komponen yang digunakan antara lain :

1. Trafo Step-down : 1 buah

2. Dioda 6A : 2 buah

3. Capasitor $2200 \mathrm{uF}: 1$ buah

4. Resistor $100 \Omega \quad: 1$ buah

Pada rangkaian power supply DC ini menggunakan output keluaran pada trafo step down dengan keluaran sebasar $25 \mathrm{~V}$. dan diode yang digunakan adalah diode silicon sebesar 6A. Gambar 5. merupakan gambar rangkaian power supply.

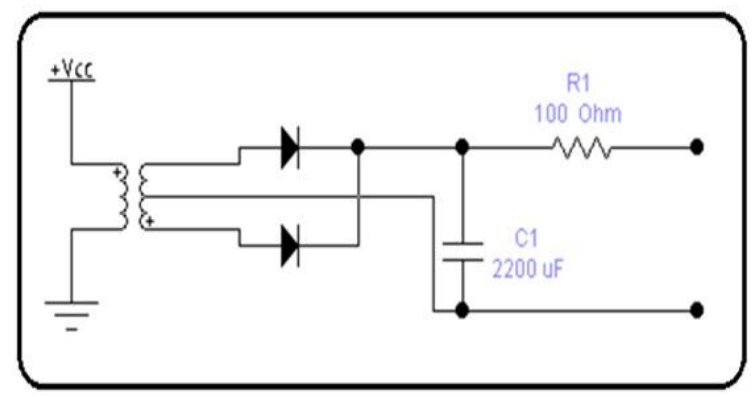

Gambar 5. Rangkaian Power Supply

Pada rangkaian power supply ini trafo masukan dari PLN ( $220 \mathrm{~V}$ ) diturunkan pada trafo step down dengan keluaran 25Volt,maka tegangan yang dihasilkan dalam perhitungan sebesar 34,25 Volt.

$$
\begin{aligned}
\mathrm{Vm}= & 25 \sqrt{ } 2-0,7=34,65 \text { Volt } \\
\mathrm{Vrms}= & \mathrm{Vm}-\left(\left(\mathrm{Vm} \times 10^{6}\right):(4 \mathrm{fRCe})\right) \\
= & 34,65-\left(\left(34,65 \times 10^{6}\right):(4 \times\right. \\
& 100 \times 100 \times 2200)) \\
= & 34,25 \text { Volt }
\end{aligned}
$$

\subsection{Regulator Tegangan}

Regulator tregangan adalah bagian power supply yang berfungsi untuk memberikan stabilitas output pada suatu power supply. Output tegangan DC dari penyearah tanpa regulator mempunyai kecenderungan berubah harganya saat dioperasikan [15-16]. Adanya perubahan pada masukan AC dan variasi beban merupakan penyebab utama terjadinya 
ketidakstabilan pada power supply. Dalam perancangan regulator tegangan ini menggunakan beberapa komponen antara lain :
1. Capasitor $10 \mathrm{uF}: 1$ buah
2. Transistor MJ2955: 2 buah
3. IC LM317 : 1 buah
4. Resistor $10 \mathrm{~K} \Omega \quad: 3$ buah
5. Resistor $240 \Omega \quad: 1$ buah
6. Capasitor $2200 \mathrm{uF}: 1$ buah

Gambar 6 merupakan gambar rangkaian Regulator Tegangan \& Penguat Arus. Pada rangkaian Regulator Tegangan ini supply tegangan dari power supply dengan keluaran tegangan 34.25VDC kemudian masuk kedalam rangkaian regulator tegangan dan penguat arus. Maka keluaran tegangan sesuai dengan perhitungan sebesar
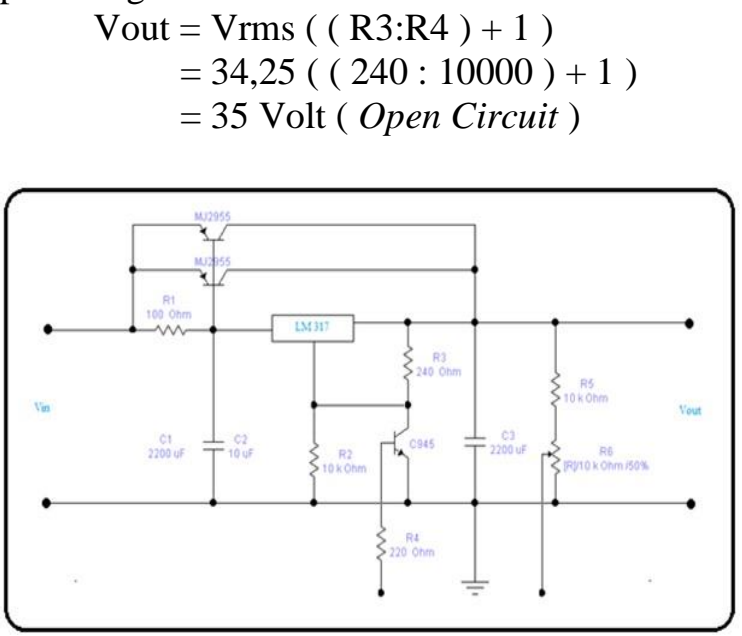

Gambar 6. Rangkaian Regulator Tegangan

\subsection{Pencacah Frequency}

Pada rangkaian penguat akhir digunakan dengan tujuan untuk mengubah tegangan DC menjadi tegangan AC dengan menggunakan gelombang DC yang dicacah menggunakan transistor 2N3055, dimana jenis transistor ini merupakan transitor daya tinggi yang nantinya akan digunakan untuk melakukan proses cutting. Gambar 7. merupakan gambar rangkaian pencacah frequency. Dalam perancangan pencacah frequency ini menggunakan beberapa komponen antara lain :

1. Resistor $100 \Omega: 2$ buah

2. Resistor $3.3 \Omega: 2$ buah

3. Capasitor $470 \mathrm{nF}: 2$ buah

4. Transistor $2 \mathrm{~N} 3055: 2$ buah

5. Trafo Step-up : 1 buah

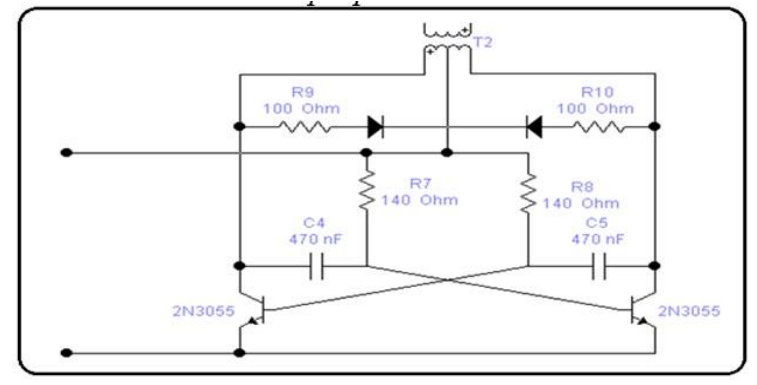

Gambar 7. Rangkaian Pencacah Frenquency

Keluaran frequency \& tegangan Vpp sesuai dengan perhitungan sebesar :

Nilai frequency:

$$
\begin{aligned}
f= & 0,7:(\mathrm{R} \times \mathrm{C}) \\
& =0,7:(140 \Omega \times 470 \mathrm{nf}) \\
& =10,63 \mathrm{KHz}
\end{aligned}
$$

Nilai Tegangan Vpp :

$\mathrm{Vrms}=\underline{\mathrm{Vmax}}$

$$
=24,7 \mathrm{Vrms}
$$

$\mathrm{Vpp}=2 . \mathrm{Vrms} . \sqrt{2}$

$$
=69,8 \mathrm{Vpp}
$$

\subsection{Rangkaian Alat Bedah}

Gambar 8. merupakan gambar rangkaian electrosurgery unit secara keseluruhan

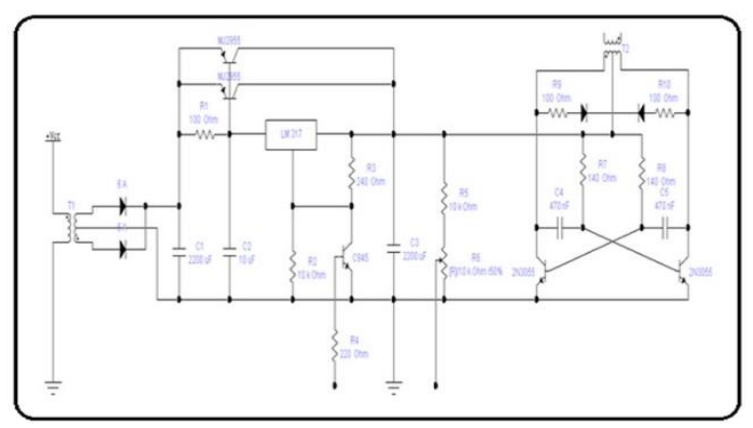

Gambar 8. Rangkaian Alat Bedah

Cara kerja rangkaian electrosurgery unit diatas yaitu pada saat trafo power supply mendapatkan supply tegangan PLN sebesar 220VAC kemudian diturunkan melalui trafo step-down dengan keluaran tegangan 32VAC, lalu di searahkan meluli diode sehingga gelombang rangkaian akan berubah menjadi VDC, maka akan mengalir tegangan VDC menuju transistor LM 317 dimana digunakan untuk regulator tegangan yang akan di atur oleh resistor variable, dan sebagian tegangan akan mengalir ke transistor MJ 2955 dimana 
transistor ini digunakan sebagai penguat arus sehingga dalam rangkaian akan mengeluarkan arus sesuai dengan data sheet yang diperoleh dari transistor tersebut. Lalu kemudian tegangan akan mengalir menuju rangkaian pencacah frequency dimana dalam rangkaian ini tegangan DC akan dicacah melalui transistor 2N3055 dimana transistor ini merupakan jenis transistor daya dan kemudian tegangan dikuatkan melalui trafo step-up, hasil dari keluaran tegangan pada trafo tersebut digunakan untuk cutting pada probe positive \& probe negative.

\section{HASIL DAN PEMBAHASAN}

Hasil perancangan alat pisau bedah yang telah dibuat dapat dilihat pada Gambar 9.

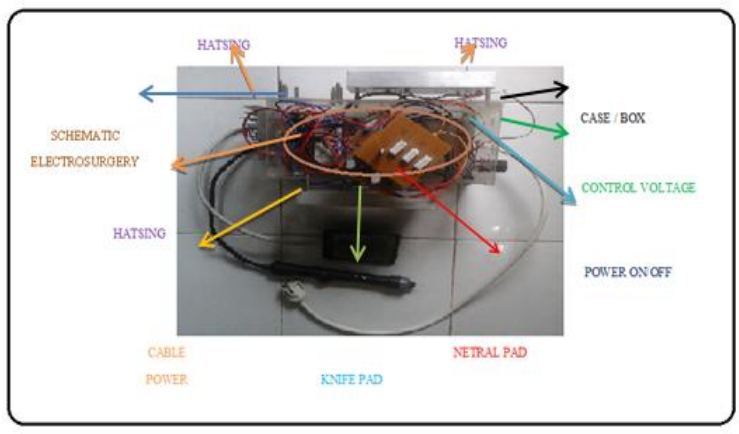

Gambar 9. Alat Pisau Bedah

\subsection{Pengujianan Power supply, regulator,} dan pencacah frekuensi

Pada rangkaian ini power supply digunakan untuk supply tegangan alat pisau bedah, maka diperlukan pengukuran terhadap kestabilan tegangan pada rangkaian power supply sebagai berikut :

Tabel 2. Hasil Pengukuran Power Supply

\begin{tabular}{|cc|}
\hline Jumlah Pengukuran & Hasil Pengukuran ( Volt ) \\
\hline \hline Pengukuran 1 & $\mathbf{3 5 , 7} \mathbf{~ V}$ \\
Pengukuran 2 & $\mathbf{3 5 , 9} \mathbf{~ V}$ \\
Pengukuran 3 & $\mathbf{3 5 , 9}$ V \\
Pengukuran 4 & $\mathbf{3 5 , 8} \mathbf{~ V}$ \\
Pengukuran 5 & $\mathbf{3 5 , 9}$ V \\
Hasil Rata - Rata & $\mathbf{3 5 , 8 4}$ V \\
\hline
\end{tabular}

Pada Tabel 2 menunjukan hasil tegangan yang dilakukan dengan pengukuran menggunakan multimeter dengan menunjukan keandalan tegangan Vout pada rangkaian power supply. Hasil tegangan ini merupakan hasil tegangan DC yang dihasilkan oleh rangkaian power supply dimana output trafo stepdown tegangan AC dirubah menjadi tegangan DC melalui diode kemudian menuju kapasitor. Dari hasil pengukuran tegangan yang dilakukan sebanyak lima kali pada rangkaian power supply yang berfungsi sebagai sumber catu daya dalam pengujian tegangan rata-rata diperoleh 35,84 Volt. Pada rangkaian ini, kestabilan tegangan yang dihasilkan sudah baik jika dibandingkan dengan hasil perhitungan berdasarkan rumus yaitu sebesar 34,25 Volt.

Pada rangkaian ini regulator tegangan digunakan untuk mengatur tegangan alat pisau bedah, maka diperlukan pengukuran terhadap kestabilan tegangan pada rangkaian regulator tegangan. Dari hasil pengukuran tegangan yang dilakukan sebanyak lima kali pada rangkaian regulator tegangan yang berfungsi sebagai pengatur tegangan DC dalam pengujian tegangan rata-rata diperoleh 35,9 Volt. Pada rangkaian ini, kestabilan tegangan yang dihasilkan sudah baik. Setelah melakukan pengukuran maka dapat dibandingkan antara hasil pengukuran yaitu sebesar 35,9 volt dengan hasil perhitungan berdasarkan rumus yaitu sebesar 35 Volt.

Tabel 3. Hasil Pengukuran Regulator Tegangan

\begin{tabular}{|cc|}
\hline Jumlah Pengukuran & Hasil Pengukuran ( Volt ) \\
\hline \hline Pengukuran 1 & $35,9 \mathrm{~V}$ \\
Pengukuran 2 & $35,8 \mathrm{~V}$ \\
Pengukuran 3 & $36,0 \mathrm{~V}$ \\
Pengukuran 4 & $35,9 \mathrm{~V}$ \\
Pengukuran 5 & $35,9 \mathrm{~V}$ \\
Hasil Rata - Rata & $35,9 \mathrm{~V}$ \\
\hline
\end{tabular}

Pencacah frequency merupakan suatu rangkaian elektronika yang berfungsi mencacah gelombang DC sehingga dapat menghasilkan sinyal frequency yang dapat dilihat pada osciloscope. Maka diperlukan pengukuran terhadap kestabilan tegangan pada rangkaian pencacah frequency sebagai berikut :

Tabel 4. Hasil Pengukuran Pencacah Frequency

\begin{tabular}{|lc|}
\hline Jumlah Pengukuran & Hasil Pengukuran ( Vrms ) \\
\hline \hline Pengukuran 1 & $28,8 \mathrm{~V}$ \\
Pengukuran 2 & $28,7 \mathrm{~V}$ \\
Pengukuran 3 & $28,7 \mathrm{~V}$ \\
Pengukuran 4 & $28,8 \mathrm{~V}$ \\
Pengukuran 5 & $28,7 \mathrm{~V}$ \\
Hasil Rata - Rata & $28,74 \mathrm{~V}$ \\
\hline
\end{tabular}


Dari hasil pengukuran tegangan yang dilakukan sebanyak lima kali pada rangkaian regulator tegangan yang berfungsi sebagai pengatur tegangan DC dalam pengujian tegangan rata-rata diperoleh $81,28 \mathrm{Vpp}$. Adapun bentuk gelombang dari rangkaian pencacah frequency ditunjukan pada Gambar 10.

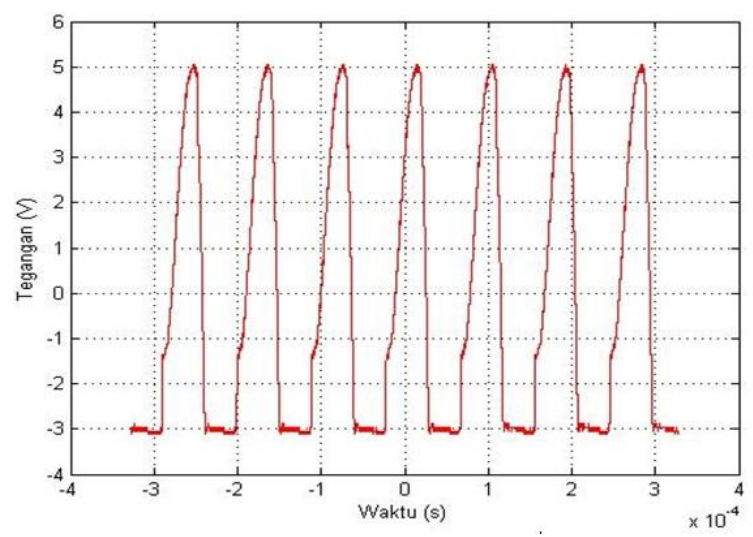

Gambar 10. Hasil Pengukuran Frequency

Dari hasil pengukuran frequency yang dilakukan pada pencacah frequency, dalam pengujian diperoleh frequency sebesar $11,16 \mathrm{KHz}$ sementara perhitungan berdasarkan rumus yaitu sebesar $10,63 \mathrm{KHz}$. Dalam pengukuran arus maksimal yang dihasilkan alat pisau bedah sebesar 0.32A, Sehingga dapat diperoleh daya maksimal sebesar :

$$
\begin{aligned}
\mathrm{P} & =\mathrm{V} . \mathrm{I} \\
& =81,28 \mathrm{~V} \cdot 0,32 \mathrm{~A} \\
& =26,0096 \text { Watt }
\end{aligned}
$$

\subsection{Pengujianan Pisau bedah kepada Daging} Sapi, Daging Kambing, Daging Kerbau

Pada perancangan pisau bedah listrik ini diperlukan pengujian alat, agar mendapatkan spesifikasi yang diinginkan, oleh karna itu dilakukan uji coba terhadap objek yang telah di tentukan. Perancangan secara keseluruhan perangkat elektro surgery ini dapat menghasilkan frequency sebesar $11,16 \mathrm{KHz}$, dan daya yang dihasilkan sebesar 26,0096 Watt, Dengan kedalaman daging $1 \mathrm{~mm}$ dan lebar $2 \mathrm{~mm}$. Tegangan divariasi antara 27,8 Volt - 28,7 Volt.

\subsubsection{Pengujian Pada Daging Sapi}

Hasil pengujian pisau bedah yang telah dilakukan dapat dilihat pada Tabel 5:
Tabel 5. Hasil Pengujian Pada Daging Sapi

\begin{tabular}{|clll|}
\hline $\begin{array}{c}\text { Tegangan } \\
(\mathrm{V})\end{array}$ & $\begin{array}{l}\text { Waktu } \\
(\mathrm{t})\end{array}$ & Kedalaman & Lebar \\
\hline \hline 28,7 Volt & $\mathbf{5 1}$ Detik & $\mathbf{1} \mathbf{~} \mathbf{~ m}$ & $\mathbf{2} \mathbf{~ m m}$ \\
28,1 Volt & $\mathbf{5 3}$ Detik & $\mathbf{1} \mathbf{~} \mathbf{~ m}$ & $\mathbf{2} \mathbf{~ m m}$ \\
27,8 Volt & $\mathbf{5 7}$ Detik & $\mathbf{1 ~} \mathbf{~ m}$ & $\mathbf{2 ~} \mathbf{m m}$ \\
\hline
\end{tabular}

Hasil pengujian pada daging sapi dapat ditunjukan pada Gambar 11.

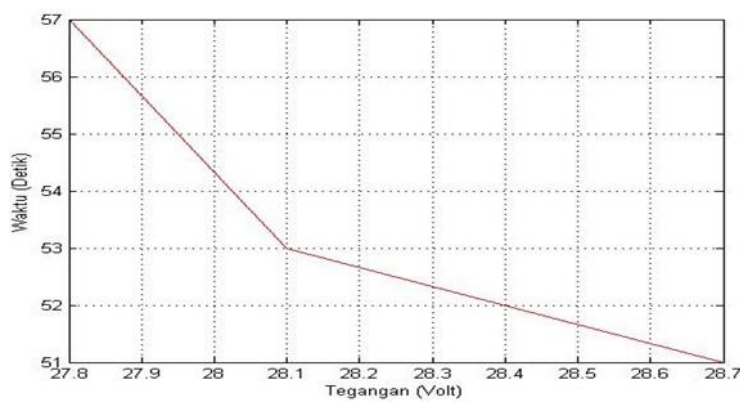

Gambar 11. Pengujian Pada Daging Sapi

Pada Grafik 11. menunjukan hubungan antara tegangan yang dibutuhkan dengan waktu yang diperlukan. Untuk memotong daging sapi dihasilkan kedalaman $1 \mathrm{~mm}$ dan lebar $2 \mathrm{~mm}$. Pada Gambar 11 memperlihatkan pada tegangan 27,8 Volt membutuhkan waktu 57detik dalam pengoprasiannya, sedangkan pada tegangan 28,1Volt membutuhkan waktu 53detik dalam pengoprasiannya, dan pada tegangan 28,7 Volt membutuhkan waktu 51detik dalam pengoprasiannya, maka dapat ditunjukan semakin rendah tegangan semakin lama pula waktu yang diperlukan, begitu pula sebaliknya. Semakin tinggi tegangan semakin cepat pula waktu yang diperlukan.

\subsubsection{Pengujian Pada Daging Kambing}

Hasil pengujian pisau bedah yang telah dilakukan dapat dilihat pada Tabel 6 :

Tabel 6. Hasil Pengujian Pada Daging Kambing

\begin{tabular}{|llll|}
\hline $\begin{array}{l}\text { Tegangan } \\
\text { ( V })\end{array}$ & $\begin{array}{l}\text { Waktu } \\
(\mathrm{t})\end{array}$ & Kedalaman & Lebar \\
\hline \hline 28,7 Volt & $\mathbf{3 0}$ Detik & $\mathbf{1} \mathbf{~} \mathbf{~ m}$ & $\mathbf{2} \mathbf{~} \mathbf{m}$ \\
28,1 Volt & 41 Detik & $\mathbf{1} \mathbf{~}$ & $\mathbf{2}$ \\
27,8 Volt & 49 Detik & $\mathbf{1 ~} \mathbf{m m}$ & $\mathbf{2} \mathbf{~} \mathbf{m}$ \\
\hline
\end{tabular}

Hasil pengujian pada daging kambing dapat ditunjukan pada Gambar 12. 


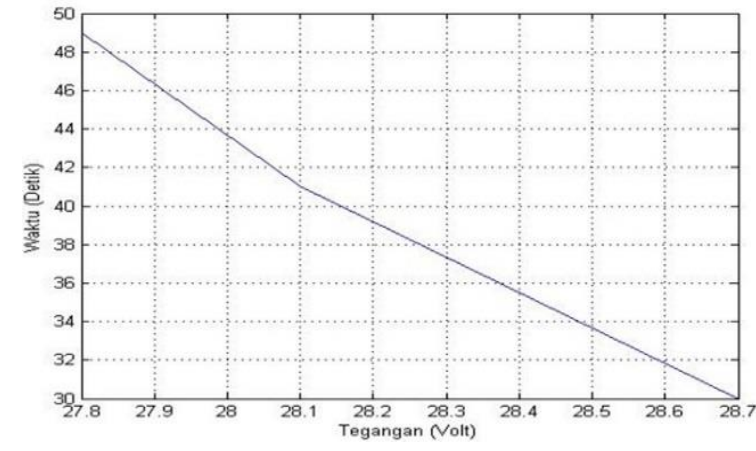

Gambar 12. Pengujian Pada Daging Kambing

Pada Gambar 13 menunjukan hubungan antara tegangan yang dibutuhkan dengan waktu yang diperlukan. Untuk memotong daging kambing dihasilkan kedalaman $1 \mathrm{~mm}$ dan lebar $2 \mathrm{~mm}$. Pada Gambar 12 memperlihatkan pada tegangan 27,8Volt membutuhkan waktu 49detik dalam pengoprasiannya, sedangkan pada tegangan 28,1 Volt membutuhkan waktu 41 detik dalam pengoprasiannya, dan pada tegangan 28,7Volt membutuhkan waktu 30detik dalam pengoprasiannya, maka dapat tunjukkan semakin rendah tegangan semakin lama pula waktu yang diperlukan, begitu pula sebaliknya. Semakin tinggi tegangan semakin cepat pula waktu yang diperlukan.

\subsubsection{Pengujian Pada Daging Kerbau}

Hasil pengujian pisau bedah yang telah dilakukan dapat dilihat pada Tabel 7 :

Tabel 7. Hasil Pengujian Pada Daging Kerbau

\begin{tabular}{|llll|}
\hline $\begin{array}{l}\text { Tegangan } \\
(\mathrm{V})\end{array}$ & Waktu & Kedalaman & Lebar \\
\hline \hline 28,7 Volt & $\mathbf{5 2}$ Detik & $\mathbf{1} \mathbf{~} \mathbf{m}$ & $\mathbf{2} \mathbf{~ m m}$ \\
28,1 Volt & $\mathbf{5 6}$ Detik & $\mathbf{1 ~} \mathbf{~ m}$ & $\mathbf{2} \mathbf{~ m m}$ \\
27,8 Volt & $\mathbf{5 9}$ Detik & $\mathbf{1 ~} \mathbf{~ m}$ & $\mathbf{2} \mathbf{~ m m}$ \\
\hline
\end{tabular}

Hasil pengujian pada daging kerbau dapat ditunjukan pada Gambar 13. Pada Gambar 13. menunjukan hubungan antara tegangan yang dibutuhkan dengan waktu yang diperlukan. Untuk memotong daging kambing dihasilkan kedalaman $1 \mathrm{~mm}$ dan lebar $2 \mathrm{~mm}$. Pada Gambar 13 memperlihatkan pada tegangan 27,8Volt membutuhkan waktu 59detik dalam pengoprasiannya, sedangkan pada tegangan 28,1Volt membutuhkan waktu 56detik dalam pengoprasiannya, dan pada tegangan $28,7 \mathrm{Volt}$ membutuhkan waktu 52detik dalam pengoprasiannya, maka dapat ditunjukankan semakin rendah tegangan semakin lama pula waktu yang diperlukan, begitu pula sebaliknya. Semakin tinggi tegangan semakin cepat pula waktu yang diperlukan.

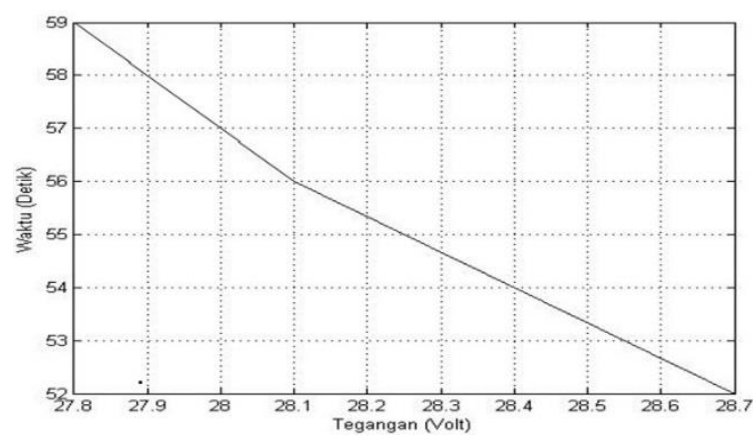

Gambar 13. Pengujian Pada Daging Kerbau

Dari ketiga pengujian yang telah dilakukan, maka dapat disimpulkan pada Gambar 14 :

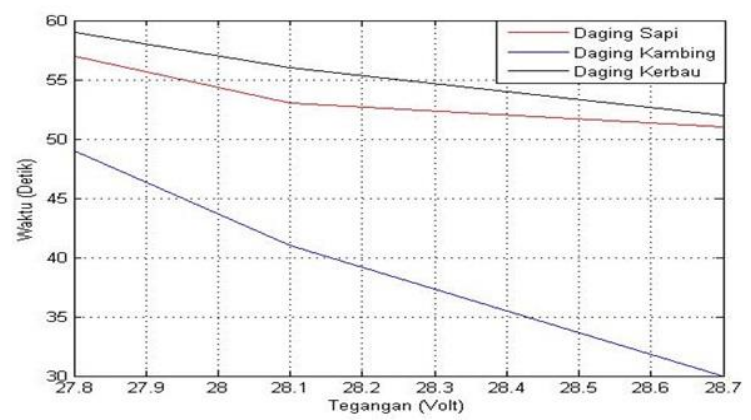

Gambar 14. Hasil Pengujian Terhadap Daging

Dari ketiga pengujian yang telah dilakukan dengan menggunakan ukuran panjang dan lebar $10 \mathrm{~cm} \mathrm{x} 10 \mathrm{~cm}$ yang masing-masing jenis daging dengan ukuran disamakan, maka dapat dilihat dari rataan waktu dari ketiga jenis daging yang dilakukan adalah :

1. Daging Sapi

$$
\frac{51+53+57}{3}=53,66 \text { detik }
$$

2. Daging Kambing

3. Daging Kerbau

$$
\frac{30+41+49}{3}=40 \text { detik }
$$

$$
\frac{52+56+59}{3}=55,66 \text { detik }
$$

Maka dari hasil perhitungan rataan waktu diatas dapat disimpulkan bahwa daging kerbau memiliki karakteristik daging paling keras 
diantara ketiga jenis ini sehingga memiliki waktu paling lama untuk hasil pemotongannya dengan membutuhkan waktu 55,66 detik dalam pengoprasiannya. Sedangkan daging kambing memiliki karakteristik daging paling lembut diantara kedua ketiga jenis ini sehingga memiliki waktu paling sedikit untuk hasil pemotongannya dengan membutuhkan waktu 40 detik dalam pengoprasiannya. Namun aging sapi memiliki karakteristik daging lebih lunak dari daging kerbau, akan tetapi memiliki karakteristik daging lebih keras dari daging kerbau, sehingga dalam pemotongannya membutuhkan waktu 53,66 detik dalam pengoprasiannya. Tabel 8 menujukan perbandingan antara perhitungan dengan perancangan alat pisau bedah.

Tabel 8. Hasil Perbandingan Antara Perhitungan Dan Pengukuran

\begin{tabular}{|lccc|}
\hline Kinerja & $\begin{array}{l}\text { Ref } \\
{[1]}\end{array}$ & Perhitungan & Pengukuran \\
\hline \hline Frequency & 450 & $10,63 \mathrm{KHz}$ & $11,16 \mathrm{KHz}$ \\
& $\mathrm{KHz}$ & & \\
Daya & 47,97 & $21,3 \mathrm{Watt}$ & 26,0096 \\
& Watt & & Watt \\
Lebar & $2 \mathrm{~mm}$ & $2 \mathrm{~mm}$ & $2 \mathrm{~mm}$ \\
Kedalaman & $1 \mathrm{~mm}$ & $1 \mathrm{~mm}$ & $1 \mathrm{~mm}$ \\
\hline
\end{tabular}

Dari Tabel 8 dapat disimpulkan perbandingan antara referensi yang didapat dengan perancangan alat pisau bedah. Dengan perbedaan frequency dari referensi menggunakan frequency $450 \mathrm{KHz}$ dengan perancangan menggunakan frequency 11,16 $\mathrm{KHz}$ dan perbedaan daya dari referensi sebesar 47,97Watt dengan perancangan menggunakan daya sebesar 26 Watt, dapat menghasilkan kedalaman \& lebar pemotongan pada hasil daging yang sama. Namun dengan daya relative rendah sehingga dapat meminimalisir adanya sparkover penyebab luka bakar.

\section{KESIMPULAN}

Alat Rancang Bangun Low Power Elektro Surgery ( Pisau Bedah Listrik ) Pada Frequency $10 \mathrm{KHz}$. Menghasilkan daya sebesar 26,0096 Watt dan frequency sebesar 11,16 KHz.

1. Pada daging sapi dengan menggunakan tegangan 28,7 Volt membutuhkan waktu 51 detik, dengan menggunakan tegangan 28,1 Volt membutuhkan waktu 53 detik, dengan menggunakan tegangan 27,8 Volt membutuhkan waktu 57 detik.

2. Pada daging kambing dengan menggunakan tegangan 28,7 Volt membutuhkan waktu 30 detik, dengan menggunakan tegangan 28,1 Volt membutuhkan waktu 41 detik, dengan menggunakan tegangan 27,8 Volt membutuhkan waktu 49 detik.

3. Pada daging kerbau dengan menggunakan tegangan 28,7 Volt membutuhkan waktu 52 detik, dengan menggunakan tegangan 28,1 Volt membutuhkan waktu 56 detik, dengan menggunakan tegangan 27,8 Volt membutuhkan waktu 59 detik.

4. Jika dibandingkan dengan hasil penelitian rancang bangun alat pisau bedah listrik ini daya rendah dan frequency rendah, sehingga dapat meminimalisir terjadinya spark over.

\section{DAFTAR PUSTAKA}

[1] Joko Sunardi, M.Fajri.S, Toto.T. 2011. Rancang Bangun Pisau Bedah Listrik Dengan Frequency $450 \mathrm{KHz}$ (ESU). Yogyakarta : STTN-BATAN

[2] Bangkit Anggun W. 2010. Analisa Ketidakpastian Electrosurgical Unit. Surabaya : ITS

[3] Daniel Palanker. 2008. Mechanism of Interaction in Electrosurgery. USA : Stanford Univerity

[4] Malvino. 2003. Prinsip-Prinsip Elektronika. Terjemah Joko Susanto. Depok: Salemba Teknik.

[5] Cooper, David, William. 1993. Instrumentasi Elektronik dan Teknik Pengukuran. Penerbit Erlangga.

[6] Hayt, H. William. 1996. Rangkaian Listrik. Penerbit ITB Bandung.

[7] Fizgerald,A,E dan Gabriel A,1985. DasarDasar Elektroteknik, Penerjemah Pantur Silaban, Edisi kelima jilid 2, Penerbit Erlangga, Jakarta.

[8] Malvino, 1996, Prinsip-Prinsip Elektronika Edisi Ke Tiga. Penerbit Erlangga.

[9] Soedjono, H. Hartanto. 2002. Merakit Elektronika. Semarang : Effar.

[10] Warsito,S,1996, Kamus Elektronika Indonesia, Edisi Yang disempurnakan, Penerbit PT.Gramedia Pustaka Utama, Jakarta.

[11] Diana S. 2011. Electro Surgical. Surabaya : Institut Teknologi Sepuluh November. 
[12] Andi Ardiansyah, Hirawan Antoni. 2010. Electro Surgical Unit Sebagai Alat Bantu Bedah. Jakarta : Universitas Mercu Buana.

[13] Matias H.W. Budhiantho, Gunawan Dewantoro, Demas Sabatino." Perancangan Penguat Awal Menggunakan Tabung Hampa Pada Aras Tegangan Rendah" Jurnal Nasional Teknik Elektro. Vol 4, No 1. 2015.

[14] Prof.Dr.Zuhal M.Sc.EE, Ir.Zhanggischan. 2004. Prinsip Dasar Elektroteknik, Penerbit PT.Gramedia Pustaka Utama, Jakarta.

[15] Malvino,A.P. Prinsip-prinsip Elektronik edisi ke 2. Alih bahasa Gunawan, Hanapi. Jakarta : Erlangga.

[16] Bishop, Owen. 2004. Dasar-Dasar Elektronika. Alih bahasa Harmein, Izham. Jakarta : Erlangga.

\section{Biodata Penulis}

Teguh Firmansyah, Lahir di Subang pada tahun 1987. Melanjutkan Studi S-1 dan S-2 di Teknik Elektro. Universitas Indoensia. dengan predikat Cumlaude. Bidang penelitian meliputi RF and Wireless Communications. Broadband and Multiband Communications. Antenna and Propagation. Wireless Sensor Networks (WSN). Internet of Thing (IoT) and Machine to Machine (M2M) Communications. Beberapa jurnal penulis, telah diterima di Jurnal Internasional terindeks. Selain itu, Penulis memiliki HKI sebanyak 3 buah. Saat ini aktif mengajar di JTE Untirta, serta tergabung dalam Wireless Antenna Communication Enginerring Studies (WACES). Teknik Elektro Untirta. 